\title{
Flexural strength of mini-implants developed for Herbst appliance skeletal anchorage. A study in Minipigs br1 cadavers
}

\author{
Klaus Barretto Lopes ${ }^{1}$, Gladys Cristina Dominguez², Caio Biasi ${ }^{3}$, Jesualdo Luiz Rossi ${ }^{4}$
}

Objective: The present study was designed to verify if mini-implant prototypes (MIP) developed for Herbst appliance anchorage are capable of withstanding orthopedic forces, and to determine whether the flexural strength of these MIP varies depending on the site of insertion (maxilla and mandible). Methods: Thirteen MIP were inserted in three minipig cadavers (six in the maxilla and seven in the mandible). The specimens were prepared and submitted to mechanical testing. The mean and standard deviation were calculated for each region. A two-way Student's t test was used to compare the strength between the sites. A one-way Student's t test was performed to test the hypothesis. Orthopedic forces above $1.0 \mathrm{kgf}$ were considered. Results: The MIP supported flexural strength higher than $1.0 \mathrm{kgf}$ $(13.8 \pm 2.3 \mathrm{Kg}$, in the posterior region of the maxilla and $20.5 \pm 5.2 \mathrm{Kg}$ in the anterior region of the mandible) with a significantly lower flexural strength in the anterior region of the mandible $(\mathrm{P}<0.05)$. Conclusion: The MIP are capable of withstanding orthopedic forces, and are more resistant in the anterior region of the mandible than in the posterior region of the maxilla in Minipigs br1 cadavers.

Keywords: Functional appliances. Dental implants. Orthodontic appliances. Orthodontic anchorage procedures. Angle Class II malocclusion.

Objetivo: o presente estudo foi delineado para verificar se protótipos de mini-implantes (PMI) desenvolvidos para a ancoragem esquelética do aparelho de Herbst são capazes de suportar forças ortopédicas e, também, determinar a variação da força de flexão desses PMI de acordo com o local de inserção (maxila ou mandíbula). Métodos: após o cálculo do tamanho da amostra, 13 PMI foram colocados em três cadáveres de Minipigs br1 (seis na maxila e sete na mandíbula). Os corpos de prova foram preparados e submetidos a um teste mecânico. Cálculos da média e o do desvio-padrão foram realizados para cada região. $\mathrm{O}$ teste $t$ de Student para duas amostras não pareadas foi utilizado para comparar a resistência dos PMI entre as regiões de inserção. O teste $t$ de Student para uma amostra foi realizado para o teste de hipótese. Foram consideradas forças ortopédicas aquelas acima de 1,0kgf. Resultados: os PMI foram capazes de suportar forças de flexão maiores que $1,0 \mathrm{kgf}(13,8 \pm 2,3 \mathrm{Kg}$ na região posterior da maxila, e $20,5 \pm 5,2 \mathrm{Kg}$ na região anterior da mandíbula), apresentando significativa menor força de flexão na região anterior da mandíbula ( $\mathrm{p}$ $<0,05)$. Conclusão: os PMI são capazes de suportar forças ortopédicas, sendo mais resistentes quando utilizados na região anterior da mandíbula do que na posterior da maxila, em cadáveres de Minipigs br1.

Palavras-chave: Aparelhos ortopédicos. Implantes dentários. Aparelhos ortodônticos. Procedimentos de ancoragem ortodôntica. Má oclusão de Angle Classe II.

${ }^{1}$ Postdoc in Orthodontics, State University of Rio de Janeiro (UERJ).

${ }^{2}$ Full professor, Department of Orthodontics, College of Dentistry, University of São Paulo (USP).

${ }^{3} \mathrm{PhD}$ Resident, Veterinary Medicine, University of São Paulo (USP).

${ }^{4}$ Postdoc in Materials Science and Engineering, University of Surrey.

" The author Klaus Barretto Lopes asserts to be the developer and patent holder of the mini-implant prototypes used in this study.
How to cite this article: Lopes $\mathrm{KB}$, Dominguez GC, Biasi C, Rossi JL. Flexural strength of mini-implants developed for Herbst appliance skeletal anchorage. A study in Minipigs br1 cadavers. Dental Press J Orthod. 2013 NovDec;18(6):124-9.

Submitted: January 27, 2012 - Revised and accepted: April 17, 2012

Contact address: Klaus Barretto Lopes

Rua Visconde de Pirajá, 550/1407 - Ipanema

Rio de Janeiro/RJ — Brazil — CEP: 22.410-002

E-mail: klausbarretto@uol.com.br 


\section{INTRODUCTION}

Implants and mini-implants have been used as orthodontic anchorages for different purposes in different locations. ${ }^{1,2,3}$ Some researchers have suggested the use of mini-implants as orthopedic anchors in animals ${ }^{4,5}$ and in the treatment of Class III malocclusions with retrusive maxillae in humans. ${ }^{6}$ However, there is little information about the use of mini-implants as orthopedic anchorage in the treatment of Class II malocclusions.

The Herbst appliance has often been used in the treatment of Class II malocclusions, because of its efficiency $^{7}$ and also because of positive effects in orthodontic and orthopedic correction. ${ }^{8}$ Nevertheless, some investigators have stated that the correction of Class II malocclusion is a result of anchorage loss, and could be responsible for negative effects, such as protrusion and gingival recession, ${ }^{9}$ on lower incisors.

Many attempts have been made to reduce the negative effects caused by the Herbst appliance on lower incisors, such as increasing the number of teeth in the mandibular anchorage, using soft-tissue anchorage, splints, and cast splints anchorage. ${ }^{10,11}$ However, these attempts were unsuccessful.

With the intention of solving these problems, a mini-implant prototype was developed for Herbst appliance anchorage, and its flexural resistance was measured in an in vitro study. ${ }^{12}$. However, a question arose with respect to the resistance strength of this mini-implant prototype when inserted into the bone. The present study was designed to evaluate if the mini-implant prototype developed for Herbst appliance anchorage is capable of withstanding orthopedic forces in Minipigs br1, and to compare the prototype resistance between the sites of insertion.

\section{MATERIAL AND METHODS}

Thirteen mini-implants (Neodent, Curitiba, Brazil), $2 \mathrm{~mm}$ in diameter and $10 \mathrm{~mm}$ in length, with attachment to Herbst appliance telescopic tubes, were inserted in three Minipigs br $1^{13,14}$ (15-month old) after they had been euthanized.

A calculation of the sample size ${ }^{15}$ was carried out by means of two pilot studies, one for the posterior region of the maxilla and another for the anterior region of the mandible of one minipig.

Based on the performance of the specimens on the graph, the sample size was calculated with the values ob- tained with a dislocation of $1.2 \mathrm{~mm}$, because after this point the strength values increased abruptly, indicating the resistance of the metal block.

Afterwards, the following statistical formula was used:

$$
n=\frac{\left(Z_{X} C_{V}\right)^{2}}{E r^{2}}
$$

Where $\mathrm{n}=$ number of specimens, $\mathrm{Z}=$ Standard deviation from normal distribution, $\mathrm{Cv}=$ Coefficient of variation, and $\mathrm{Er}=$ Relative error.

After sample size calculation, the number of specimens needed for the final study was 6 in the maxilla and 7 in the mandible.

In order to test sample normality, the KolmogorovSmirnov test was carried out. To test the hypothesis, a one-way Student's t test was performed with Minitab 15 (State College, PA, USA). Orthopedic forces above 1 Kgf were considered. ${ }^{16,17}$

Thereafter, the hypotheses of withstanding orthopedic forces were defined ( $\mathrm{H} 0: \mu=1.0$ and $\mathrm{H} 1: \mu>1.0)$.

The criterion to reject the null hypothesis was:

tcal $>$ t $\alpha, \mathrm{n}-1$,

where $\alpha=0.05$ or calculated:

$\mathrm{t}>\mathrm{t}$ from $\mathrm{t}$ table.

To compare the flexural strength between the posterior region of the maxilla and the anterior region of the mandible, a two-way Student's t test was calculated using Minitab 15.

\section{Experiment}

The animals were euthanized before the experiment and frozen at a temperature of $-20^{\circ} \mathrm{C}$.

Two minipigs received four mini-implants (two in each maxilla and two in each mandible), and one minipig received five mini-implants (two in the maxilla and three in the mandible).

Six specimens with the new mini-implant were obtained from the posterior region of the maxilla, and seven specimens were obtained from the anterior region of the mandible, which were the possible places where the miniimplants could be used to anchor the Herbst appliance.

After that, the straight telescopic tube was placed in the head of the mini-implant with a suitable screw (Fig 1).

To create a guide for the mini-implant, a drill with torque control with a $1.3 \mathrm{~mm}$ diameter bur (Neodent, Curitiba, Brazil) was used. The insertion sites were in 
the posterior region of the maxilla, between the roots of the upper first molar and the anterior region of the mandible, between the roots of the second premolar and the roots of the third premolar.

To insert the mini-implant, a torque key with a torque meter calibrated at a measure not greater than $30 \mathrm{Kgf.cm}$ was used. When the insertion was completed, new radiographs were taken to check the final positioning of the mini-implants.

To prepare the specimens, the maxilla and the mandible were sectioned into small pieces, using an electric cutting machine. Metal blocks were used to protect the specimens during the experiment. Afterwards, an acrylic resin was used to fix the bone fragments with the mini-implants (Fig 2).

The specimens were placed in an Instron 4400R test machine (Instron, Norwood, MO, USA), with the metal block in the lower part and the telescopic tube in the upper part (Fig 3).

The specimens were submitted to a single cantilever flexure test. Traction was applied at $0.5 \mathrm{~mm}$ per minute until $1.5 \mathrm{~mm}$ of dislocation was obtained. This value was based on a pilot study carried out by Brettin et al. ${ }^{18}$ The values were recorded, and a graph of strength $\mathrm{x}$ dislocation was constructed.

\section{RESULTS}

Single cantilever flexure tests were successfully carried out on 13 specimens. The graphs illustrate the performance of the specimens during the tests in the maxilla and the mandible (Figs 4 and 5). The mini-implant prototypes showed a flexural strength of $13.86 \pm 2.30 \mathrm{Kgf}$ for the posterior region of the maxilla, and $20.5 \pm 5.20 \mathrm{Kgf}$ for the anterior region of the mandible.
The normality of the two samples was confirmed with the Kolmogorov-Smirnov test.

For the hypothesis test, the calculated t was 13.71 $(\mathrm{P}<0.001)$ for the posterior region of the maxilla. The critical t obtained from the table was 2.015. The criterion used to reject the null hypothesis revealed that:

tcal > t $\alpha, n-1$, where $\alpha=0.05 \rightarrow 13.71>2.015$

Therefore, the value calculated for $\mathrm{t}$ for the posterior region of the maxilla is outside the region of $\mathrm{H}_{0}$ acceptance. The null hypothesis was rejected, and the hypothesis that mini-implants cannot withstand orthopedic forces could not be confirmed for the posterior region of the maxilla.

Using the same criterion for the anterior region of the mandible, the calculated t was $9.94(\mathrm{P}<0.001)$. The critical t obtained from the table was 1.943.

The criterion used to reject the null hypothesis revealed that:

tcal > t $\alpha, n-1$, where $\alpha=0.05 \rightarrow 9.94>1.943$

Similarly to the maxilla, the value calculated for $t$ is outside the region of $\mathrm{H}_{0}$ acceptance. The null hypothesis was rejected, and the hypothesis that mini-implants cannot withstand orthopedic forces could not be confirmed for the anterior region of the mandible.

A statistically significant difference was found in the flexural strength between the posterior region of the maxilla and the anterior region of the mandible $(\mathrm{P}=0.015)$ : the anterior region of the mandible was significantly more resistant.

\section{DISCUSSION}

One of the purposes of this study was to quantify the flexural resistance of the mini-implant prototypes when inserted in the posterior region of the

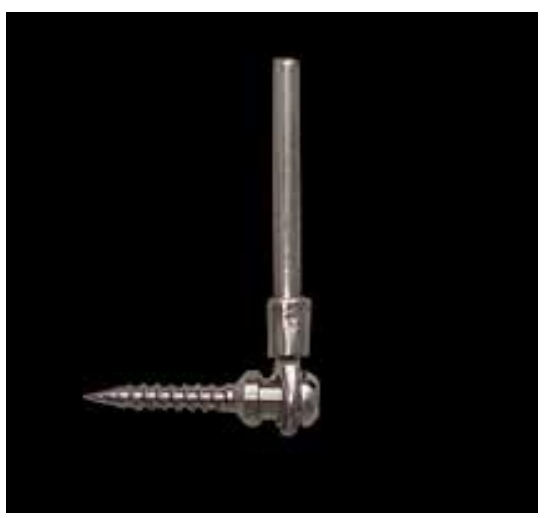

Figure 1 - Straight telescopic tube placed in the head of the mini-implant with a suitable screw.

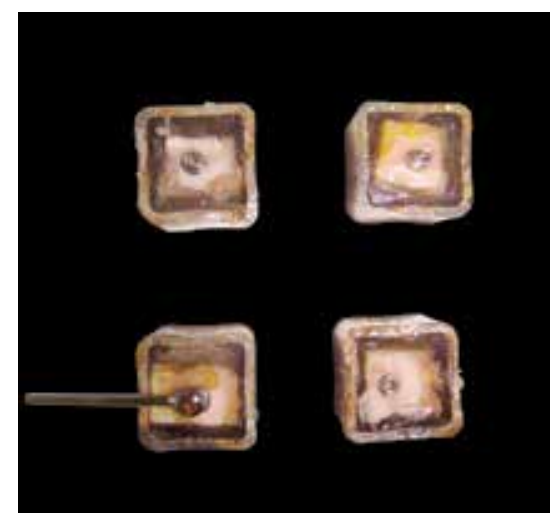

Figure 2 - Bone fragments with mini-implants inserted which were included in the metal block.

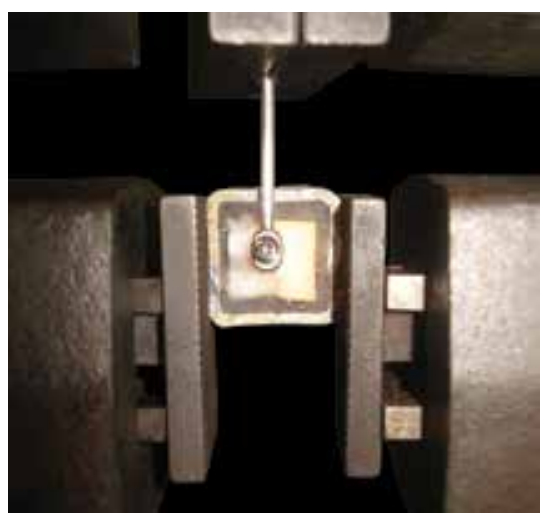

Figure 3 - Specimen ready for flexure test. 


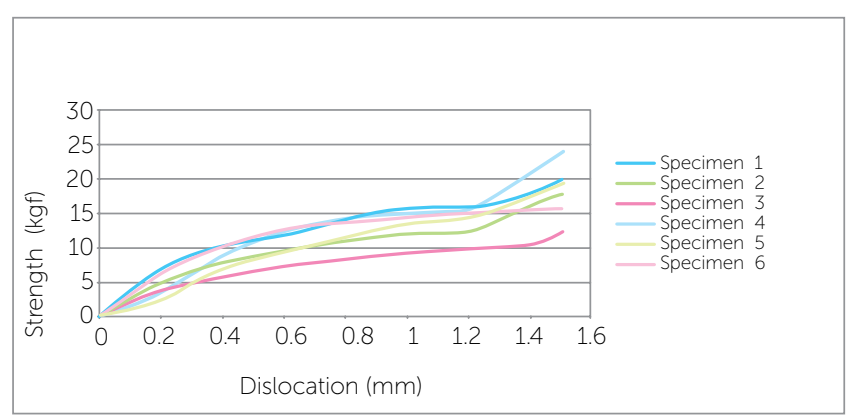

Figure 4 - Graph of strength $x$ dislocation of six specimens tested in the posterior region of the maxilla.

maxilla and the anterior region of the mandible. Although studies involving extrapolations from animals to humans should be viewed with caution, the authors' intention was to assess the strength that the mini-implant prototypes could withstand in specific regions in a Minipig br1. The mini-implant prototype showed a flexural strength of $13.86 \pm 23.0 \mathrm{Kgf}$ for the posterior region of the maxilla, and $20.55 \pm 5.20 \mathrm{Kgf}$ for the anterior region of the mandible. Another purpose of this study was to test the hypothesis that miniimplant prototypes are not capable of withstanding orthopedic forces. The hypothesis was rejected.

Miyawaki et $\mathrm{al}^{3}$ reported that the success rate of mini-implants with a $1.0-\mathrm{mm}$ diameter was significantly lower than that of other mini-implants with $1.5-\mathrm{mm}$ or $2.3-\mathrm{mm}$ diameters. This author suggested the use of mini-implants with a $1.5-\mathrm{mm}$ diameter for patients with average-to-low mandibular plane angle, and a 2.3-mm diameter for patients with a high mandibular plane angle (i.e., with a thin cortical bone). Miyawaki et $\mathrm{l}^{3}$ did not find a significant association between the success rate and the miniimplant length. However, Brettin et $\mathrm{a}^{18}$ concluded that bicortical mini-implants provide superior anchorage resistance, reduced cortical bone stress, and superior stability when compared with monocortical mini-implants. Also, according to Barros et a ${ }^{19}$ increases in mini-implant diameters significantly influenced the increases in placement torque and fracture torque on quantities that progressively reduced the fracture risk. Therefore, in order to increase the resistance of the mini-implant prototype, the diameter was increased to $2.0 \mathrm{~mm}$ and the length to 10 $\mathrm{mm}$, so as to achieve bicortical anchorage.

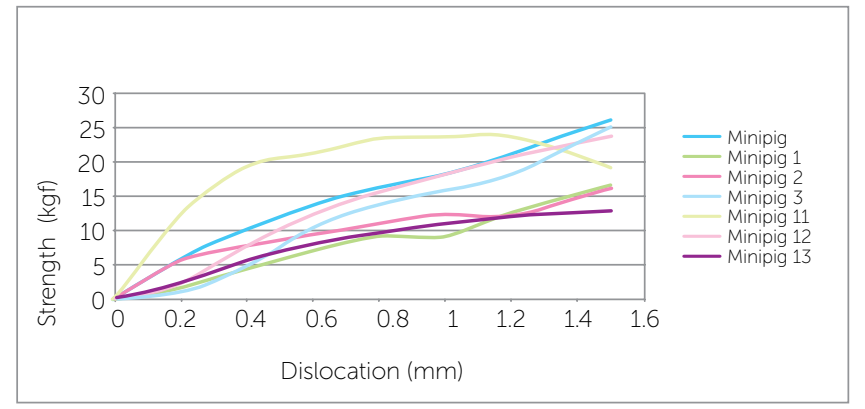

Figure 5 - Graph of strength $\mathrm{x}$ dislocation of the seven specimens tested in the anterior region of the mandible.

It could be argued that the $2.0-\mathrm{mm}$ diameter mini-implant is too large for the inter-radicular space. However, Poggio et al. ${ }^{20}$ showed that, in humans, this size is compatible with the inter-radicular distance between the upper first molars and second premolars and between the lower cuspids and the first premolars $(3 \mathrm{~mm}$ when the distance from the alveolar crest is $8 \mathrm{~mm}$ ). This is the location suggested for the insertion of the mini-implant prototypes for the Herbst appliance anchorage.

Two pilot studies were performed before the experiment to test the researchers' abilities and to calculate the sample size. ${ }^{15}$ The number of specimens was calculated in order to obtain scientific validation with the fewest possible specimens and animals.

In the present study, the mini-implant prototypes were inserted after the animals had been euthanized. Huja et $\mathrm{al}^{21}$ explained that no healing period or adaptive response could occur, and resistance strength was an indication of primary stability. Therefore, the values found in the present study are similar to the experiments of immediate loading after placement. Some studies have evaluated bone contact according to the healing period, recommending immediate loading after placement., 1,22,23

Storage conditions of the specimens used in the study have been associated with differences in pull-out strengths during mechanical traction testing. Simonian et $\mathrm{al}^{24}$ found lower pull-out strengths in frozen specimens. However, Roe et $\mathrm{al}^{25}$ reported no significant difference when the test was performed no later than one week after storage at $-20^{\circ} \mathrm{C}$. Therefore, to avoid any influence of storage conditions on the results, the specimens used in this study were prepared 
on the same day or on the day after insertion of miniimplants, frozen at $-20^{\circ} \mathrm{C}$ and tested between one and seven days after mini-implant insertion.

A single cantilever flexure test was performed instead of a shear force test and traction test, because there was a distance of $4 \mathrm{~mm}$ between the block base and the point of force application. In a shear force test, the point of force application should be parallel to the block base. A traction test would not reproduce the perpendicular strength received by the mini-implant when used as an anchorage for the Herbst appliance.

Brettin et $\mathrm{a}^{18}$ also performed a cantilever flexure tests, but in human cadavers. They found lower values than those of the present study $(20.55 \mathrm{kgf}$ for bicortical mandibular mini-implants and 13.86 kgf for monocortical maxillary mini-implants in Minipigs, against $11.0 \mathrm{kgf}$ for bicortical mandibular mini-implants and $9.0 \mathrm{kgf}$ for bicortical maxillary mini-implants, $5.0 \mathrm{kgf}$ for monocortical maxillary mini-implants and $7.0 \mathrm{kgf}$ for monocortical mandibular mini-implants in human cadavers). This difference may be related to the larger diameter of the mini-implants used in the Minipigs $(2.0 \mathrm{~mm}$ in the Minipigs against $1.6 \mathrm{~mm}$ in the human cadavers) or increased cortical bone thickness in the Minipigs.

The cantilever test is a static test. Probably, if dynamic forces had been applied to the mini-implants, different results would have been obtained. Future in vivo studies using the Herbst appliance anchored in bone will answer this question.

According to Huja et $\mathrm{al}^{21}$ some possible problems were related to cantilever tests, namely: standardization, reproducibility, bone flexure and collision of the mini-implants with adjacent root of the tooth. These problems could negatively influence accuracy of results regarding the flexural strength of the mini-implants. In this research, these possible problems were avoided, because the flexural strength of the miniimplants was obtained following the experiment performed by Brettin et $\mathrm{al}^{18}$ in which the mini-implants were tested with dislocation of $1.5 \mathrm{~mm}$. Those authors performed a pilot study in cadavers in which they concluded that the mini-implants could present mobility with dislocation above $1.5 \mathrm{~mm}$.

To test the hypothesis, orthopedic forces above $1.0 \mathrm{kgf}$ were considered. This value is very common in Orthodontics, in clinical work and research, because of the headgear which functions with 500 g per side. ${ }^{16,17}$ Other studies showed the use of orthopedic forces (from 500 to $800 \mathrm{~g}$ ) on implants ${ }^{4,5,6}$ and a few focused on the use of orthopedic forces in mini-implants, such as the study by Büchter et $\mathrm{al}^{26}$ who found that mini-implants resisted up to $900 \mathrm{~g}$ without mobility.

The flexural strength differed significantly between the posterior region of the maxilla and the anterior region of the mandible. However, this result may have been influenced by the fact that the mini-implants fixed in the mandible had bicortical anchorage while those fixed in the maxilla apparently did not have this anchorage. Probably, the distance between the cortical bones in the maxilla in the posterior region was greater than $6 \mathrm{~mm}$ or the corticallingual was not accessible due to the palate being too low. Because the mini-implant was $10 \mathrm{~mm}$ long, the active part was only $6 \mathrm{~mm}$. This suggests that in future studies the mini-implants should be constructed according to the distance between the cortical bone, as Brettin et $\mathrm{l}^{18}$ did with human cadavers.

Other forces that could affect the resistance of the mini-implant prototypes could be those originating from muscles and soft tissues of the face, due to mandibular advancement caused by functional appliances. However, earlier studies ${ }^{27,28}$ showed that the forces delivered to the teeth by functional appliances were of low intensity (80 and $160 \mathrm{gf}$ ).

The question that arises is whether to use mastication forces as a parameter rather than the orthopedic forces. According to Pancherz and Anehus-Pan$\mathrm{cherz}^{29}$, there is no contact in the posterior teeth after the installation of the Herbst appliance. The contact occurs only in the anterior teeth. This is responsible for the decrease in mastication efficiency as well as in temporal and masseter muscle activity in the first three months of treatment. After that, the authors observed an increase in the mastication forces during six months of treatment.

The forces transmitted to the teeth when using the Herbst appliance are probably the best parameter. However, it was not possible to locate studies with the data that is necessary to carry out a statistical analysis, and the force transmitted to the miniimplants in the skeletal anchorage of the Herbst appliance remains unknown. 
Thus, in vivo and clinical studies are necessary to assess the possibility of using the Herbst appliance skeletal anchorage in humans.

\section{CONCLUSION}

The mini-implant prototypes developed for Herbst appliance skeletal anchorage are capable of withstanding orthopedic forces in Minipigs br1 cadavers. The prototypes are more resistant in the anterior region of the mandible than in the posterior region of the maxilla.

\section{REFERENCES}

1. Deguchi T, Takano-Yamamoto T, Kanomi R, Hartsfield JK, Roberts WE, Garetto LP. The use of small titanium screws for orthodontic anchorage. J Dent Res. 2003:82(5):377-81.

2. Kanomi R. Mini-implant for orthodontic anchorage. J Clin Orthod. 1997:(31):763-7.

3. Miyawaki S, Koyama I, Inoue M, Mishima K, Sugahara T, Takano-Yamamoto T. Factors associated with the stability of titanium screws placed in the posterior region for orthodontic anchorage. Am J Orthod Dentofacial Orthop. 2003:124(4):373-8.

4. De Pauw GA, Dermaut L, De Bruyn H, Johansson C. Stability of implants as anchorage for orthopedic traction. Angle Orthod. 1999;69(5):401-7.

5. Smalley WM, Shapiro PA, Hohl TH, Kokich VG, Bränemark PI. Osseointegrated titanium implants for maxillofacial protraction in monkeys. Am J Orthod Dentofacial Orthop. 1988:94(4):285-95.

6. Enacar A, Giray B, Pehlivanoglu, M, Iplikcioglu H. Facemask therapy with rigid anchorage in a patient with maxillary hypoplasia and severe oligodontia. Am J Orthod Dentofacial Orthop. 2003:123(5):571-7.

7. Bremen JV, Pancherz H. Efficiency of Class II division 1 and Class II division 2 treatment in relation to different treatment approaches. Semin Orthod. 2003:(9):87-92.

8. Franchi L, Baccetti T, MCNamara J. Treatment and posttreatment effects of acrylic splint Herbst appliance therapy. Am J Orthod Dentofacial Orthop. 1999;115(4):429-38

9. Yared KF, Senobio EG, Pacheco W. Periodontal status of mandibular central incisors after orthodontic proclination in adults. Am J Orthod Dentofacial Orthop. 2006:130(1):6.e1-8.

10. El-Fateh T, Ruf S. Herbst treatment with mandibular cast splints-revisited. Am J Orthod Dentofacial Orthop. 2011;81(5):820-7.

11. Weschler D, Pancherz $\mathrm{H}$. Efficiency of three mandibular anchorage forms in Herbst treatment: a cephalometric investigation. Angle Orthod. 2005:75(1):23-7

12. Barretto-Lopes K, Dominguez G, Tortamano A, Rossi JL, Vigorito JW. Avaliação in vitro da resistência à flexão de um protótipo de mini-implante desenvolvido para ancoragem do aparelho de Herbst. Dental Press J Orthod. 2010;15(4):38e1-6. Disponivel em: http://www.scielo.br/pdf/dpjo/ v15n4/06.pdf.

13. Mariano M. Minisuíno (minipig) na pesquisa biomédica experimental. O Minipig br1. Acta Cir Bras. 2003:18(5):387-91.

14. Oltramari PVP, Navarro RL, Henriques JFC, Capelozza ALA, Granjeiro JM. Dental and skeletal characterization of the BR-1 minipig. Vet J. 2007:173(2):399-407

15. Aguilar-Nascimento JE. Fundamental steps in experimental design for animal studies. Acta Cir Bras. 2005:20(1):2-8.
16. Tanne K, Matsubara S. Association between the direction of orthopedic headgear force and sutural responses in the nasomaxillary complex. Angle Orthod. 1996:66(2):125-30

17. Almeida-Pedrin RR, Henriques JFC, Almeida RR, Almeida MR, McNamara JA Effects of the pendulum appliance, cervical headgear, and 2 premolar extractions followed by fixed appliances in patients with Class 11 malocclusion. Am J Orthod Dentofacial Orthop. 2009;136(6):833-42.

18. Brettin BT, Grosland NM, Qian F, Southard KA, Stuntz TD, Morgan TA, et al. Bicortical vs monocortical orthodontic skeletal anchorage. Am J Orthod Dentofacial Orthop. 2008:134(5):625-35.

19. Barros SE, Janson G, Chiqueto K, Garib DG, Janson M. Effect of miniimplant diameter on fracture risk and self-drilling efficacy. Am J Orthod Dentofacial Orthop. 2011:140(4):e181-92.

20. Poggio PM, Incorvati C, Velo S, Carano A. "Safe zones": A guide for miniscrew positioning in the maxillary and mandibular arch. Angle Orthod. 2006;76(2):191-7

21. Huja SS, Litsky AS, Beck FM, Johnson KA, Larsen PE. Pull-out strength of monocortical screws placed in the maxillae and mandibles of dogs. Am J Orthod Dentofacial Orthop. 2005:127(3):307-13.

22. Huja SS, Rao J, Struckhoff JA, Beck FM, Litsky AS. Biomechanical and histomorphometric analyses of monocortical screws at placement and 6 weeks postinsertion. J Oral Implantol. 2006:32(3):110-6.

23. Salmória KK, Tanaka OM, Guariza-Filho O, Camargo ES, Souza LT, Maruo H. Insertional torque and axial pull-out strength of mini-implants in mandibles of dogs. Am J Orthod Dentofacial Orthop. 2008;133(6):790.e15-22.

24. Simonian PT, Conrad EU, Chapman JR, Harrington RM, Chansky HA. Effect of sterilization and storage treatments on screw pullout strength in human allgraft bone. Clin Orthop Relat Res. 1994:302:290-6.

25. Roe SC, Pijanowski GJ, Johnson AL. Biomechanical properties of canine cortical bone allografts: effects of preparation and storage. Am J Vet Res. 1988:49:6:873-7

26. Büchter A, Wiechmann D, Gaertner C, Hendrik M, Vogeler M. Wiesmann HP, et al. Load-related bone modelling at the interface of orthodontic micro-implants. Clin Oral Implants Res. 2006:17(6):714-22

27. Noro T, Tanne K, Sakuda M. Orthodontic forces exerted by activators with varying construction bite heights. Am J Orthod Dentofacial Orthop 1994:105(2):169-79.

28. Katsavrias EG, Halazonetis DJ. Intermaxillary forces during activator treatment. Am J Orthod Dentofacial Orthop. 1999:115(2):133-7.

29. Pancherz $H$, Anehus-Pancherz $M$. The effect of continuous bite jumping with the Herbst appliance on the masticatory system: a functional analysis of treated Class II malocclusions. Eur J Orthod. 1982;4(1):37-44. 